\title{
Achievements and lesson learned assessment of the 2010 Merapi eruption disaster management: an initial stage to sustainable volcano disaster risk reduction
}

\author{
Widodo Pawirodikromo ${ }^{1 *}$ \\ ${ }^{1}$ Department of Civil Engineering and Disaster Risk Management \\ Faculty of Civil Engineering and Planning, Islamic University of Indonesia, Yogyakarta, Indonesia
}

\begin{abstract}
The Mw6.3 of 2006 Yogyakarta earthquake and the VEI4 of 2010 Merapi Volcano eruptions at Yogyakarta Special Province (YSP) have shocked the Yogyakarta community. It is necessary, therefore, to identify and to explore the achievements and the lesson learned mainly during the early warning, evacuation, emergency response and disaster recovery phases of the 2010 Merapi eruption. Research on the 2010 Merapi eruption disaster management (DM) focusing on the emergency response and disaster recovery up to 2014 has been done. Results of the investigation showed that in general Disaster Management has been applied appropriately including material qualities and construction quality of earthquake resistant structure. Among the achievements in the DM respectively are the accuracy of monitoring the direction of mountain summit deformation, successfully prediction and evacuation of people before 2010 Merapi eruption, quick resettlement buildings based on the principles of earthquake resistant structure. Meanwhile among the lesson learned to improve the DM respectively are the early warning should be presented as clear as possible, the government should officially be carried out regular "tell story" to community about the development of the disaster threat, building disaster knowledge and awareness to community for reducing the risk should be regularly carried out and the skills of the builders should be well prepared. Implementation of resilience in schools and villages, sister school and village are efforts toward Sustainable Disaster Risk Reduction.
\end{abstract}

\section{Introduction}

The disaster event is often defined whenever the impacts of the hazard seriously disrupted the functioning daily life of a community which exceeds the ability of the affected community to cope with their own resources. The impact of the disaster may cover a wide range of community daily life both in the physical and non-physical aspect. The physical aspect covers the possible fatalities and any physical damage. The non-physical aspect includes psychosocial, demographic and political impacts [1]. Data that have been collected by [1] indicated that Asia was the most vulnerable region in the world. According to the data, Asia experiencing $54 \%$ of the earthquakes in the world but caused $71 \%$ of the casualties from these events. In contrast, American experiencing $22 \%$ of the earthquakes but only caused $17 \%$ of the casualties from these events.

Indonesia is one of the Asian countries which is facing the problems caused by not only the natural but also the man-made disasters. According to the data issued by the Indonesian National Agency for Disaster Management, the most frequents of the natural hazard in the year 2016 was a flood, then followed by fires, drought, landslides, tidal waves, earthquakes, and volcano eruptions. The natural disaster caused by volcano eruption basically is in the least frequent but the Sinabung mount at North Sumatra erupted continuously.

The first eruption was in August 2010 then followed by September 2013, January 2015 and May 2016. The severity of the refugees cannot be measured since there is no clear sign or evidence when the eruption will be terminated. By considering those volcano eruptions, efforts particularly in preparedness, early warning and recovery in the Disaster Management (DM) to mitigate the risk should be properly carried out. Fortunately, the development of the disaster risk reduction in DM has been long developed and discussed [2] and finally leads to a formal framework as presented by [3] and [4].

Mount Merapi as presented in Fig. 1 is one of the most active volcanoes not only in Indonesia but also around the world. Mount Merapi erupts with Volcano Eruption Index (VEI) vary from small to moderate where collapsed of the dome is followed by pyroclastic flows [5].

\footnotetext{
") Corresponding author : widodo355@gmail.com,785110201@uii.ac.id
} 


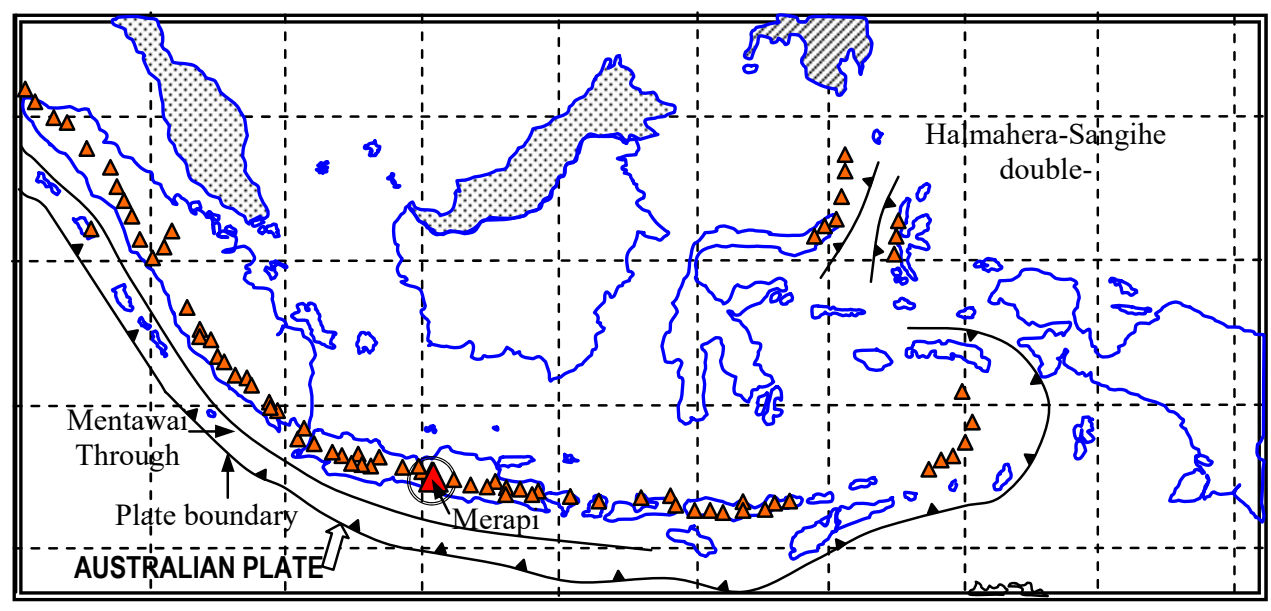

Fig. 1. The Indonesian volcanic arches

The lesson learned of the 2010 Merapi and Sinabung eruptions was carried out by [6]. The characteristic of Merapi and Sinabung volcano monitoring and eruption process were evaluated and compared. Unlike the Merapi volcano, there is no monitoring system installed at Sinabung since the mountain has been 400 years long sleep. Accordingly, there was no progressive early warning to the community by the government. In contrast, Merapi were repeatedly eruptions with the return periods ( 4 years including in 2010). As presented earlier, the mount of Sinabung erupted continuously from 2010 to 2016 while Merapi was only a single eruption at 2010 and stopped. Lesson learned by [6] were more emphasized on the necessary quick response and monitoring of any volcanic crisis.

Discussion of the lesson learned of the evacuation of 2010 Merapi eruption has been presented by [5]. The discussion started with the people living on the flanks of Merapi who were vulnerable to the volcano eruption. The schedules for people evacuation, the methods of evacuation, the method of communication as well as the field condition for evacuation roads were also presented. The paper also presented the preparation before the 2010 Merapi eruption i.e. the building community resilience through community education, evacuation drills and enhancement of the government capacity by quality improvement of evacuation road paving. The results indicated that those peoples who were adequately prepared for disaster crisis perform better, understood and obey and fewer fatalities rather than who were not. This investigation was emphasized on the disaster evacuation.

The 2010 Merapi eruption caused more than 2650 houses totally destroyed. Of course, there is none number of houses available for resettlement as many as destroyed in a very short time. The government policy was then to provide a temporary resettlement to the victims before constructing the new housing in the reconstruction phase. The perception of the people who stayed in the permanent resettlement was investigated by [7]. The investigation was carried out with involving: 1) facility sufficiency; 2) neighbor networking; 3) environmental freshness; 4) comparison with the previous house; 5) size of house sufficiency; 6) hazard safety and 7) distance from the house to the workplace. The result of the investigation shows that in general, the beneficiaries satisfy the resettlement facilities and condition that had already been provided by the government.

Research on the sustainability and vulnerability of the 2010 Merapi eruption resettlement was conducted by [8]. This research basically is the combination of psychological and architectural disciplines and leads to phenomenology based paradigm. All required data cover 100 households at Glagaharjo village Cangkringan sub-district. The data were collected from the questionnaire and further to be analyzed quantitatively by using the statistical analysis program. The result of the research indicated that the social and emotional bond is an important consideration and several criteria (distance, economic, access) should be provided in the resettlement program.

Research on the effects of DM programs to individual preparedness was intensively conducted by [9] at several sub-districts in Sleman, Yogyakarta. In this research, 8latent variables were used to describe the quantitative relationship between the DM programs with the respondent perception after the 2010 Merapi eruption disaster. The perceptions were collected from 192respondents through questionnaire and dept-interview. The data was analyzed through 2-steps; firstly the path model estimation and secondly to generate the key results. Results of the investigation indicated that only one latent variable provide score greater than 4.0 cut-off basic for respondent satisfaction and DM implementation needs to be improved in the future.

This study or assessment mainly was carried out at Yogyakarta Special Province particularly at Sleman Regency, i.e. the area which was most severely affected by 
the 2010 Merapi eruption. This study presents the facts that have not been presented in previous studies, for instance, the implementation of the recovery policy by [10] as presented in [11] as well as the principles of sustainable disaster risk reduction as presented by [12]. In this investigation, 3-phases in the disaster management i.e. the disaster early warning, disaster response, and disaster recovery have been scrutinized and evaluated. Results of the investigation are presented in term of gained achievements, lesson learned and efforts to develop sustainable disaster risk reduction.

\section{The material and method}

The research particularly was conducted during the emergency response (2010) and disaster recovery (2014) phases. Disaster recovery is a complex and challenging process that involves all sectors of the community as well as outside interest stakeholders [13], however, in this study only emphasized on the housing reconstruction sector. The types of materials used in the housing reconstruction sector include the concrete, reinforcing steel, timber, clay roof tile, and ceramic tiles. Since Yogyakarta is one of the earthquake-prone areas, then housings should be constructed according to the principle of Earthquake Resistant Structure (ERS). Moreover, the quality of materials used must meet the requirements of earthquake resistant building construction.

Meanwhile, the methods of investigation were conducted through the direct observations and collecting data on site, interview and discussion, focus group discussion (FGD), site and laboratory test, gathering information from the papers/journals, general information from media and on the spot photos in the sites. The methods of investigation are covering the following items.

\subsection{Site observation and data collection}

According to FEMA P-759, the concept of ERS covers several criteria. Among the most important criteria particularly for non-engineered housing are presented in Table. 1 and the building elements and its parameters are presented in Table 2. All data are collected from site observation and measurements.

Table 1. The ERS criteria and parameters

\begin{tabular}{|l|l|l|l|}
\hline No. & \multicolumn{1}{|c|}{ ERS Criteria } & \multicolumn{2}{|c|}{ Parameters } \\
\hline 1 & Structural Integrity & Completeness of structural elements & Connection between elements \\
\hline 2 & Structural Strength & Material quality and steel bar content & Size of elements \\
\hline 3 & Structural Stiffness & Concrete quality & Length and size of elements \\
\hline 4 & Ductility \& Stability & Concrete and steel bar quality & Shear reinforcement \\
\hline
\end{tabular}

Table 2. Building aspects and parameter applied in the earthquake resistant houses

\begin{tabular}{|c|c|c|c|c|c|c|c|}
\hline No & Build. Elements & \multicolumn{6}{|c|}{ Parameters } \\
\hline $\mathrm{P}_{1}$ & Foundation & $\begin{array}{l}\text { The sand base } \\
\text { layer } \\
\text { thickness }\end{array}$ & $\begin{array}{l}\text { Stone base } \\
\text { thickness }\end{array}$ & $\begin{array}{l}\text { Found. Base } \\
\text { size }\end{array}$ & $\begin{array}{l}\text { Top found. } \\
\text { size }\end{array}$ & $\begin{array}{l}\text { Found. } \\
\text { height }\end{array}$ & Mortar Mix \\
\hline $\mathrm{P}_{2}$ & Tie beam & Tie beam width & Tie beam height & Bar diameter & Stirrup dia. & Stirrup dist1 & Stirrup dist 2 \\
\hline $\mathrm{P}_{3}$ & $\begin{array}{l}\text { Practical } \\
\text { column }\end{array}$ & $\begin{array}{l}\text { Column } \\
\text { Width }\end{array}$ & Column depth & Bar diameter & $\begin{array}{l}\text { Stirrup } \\
\text { diameter }\end{array}$ & $\begin{array}{l}\text { Stirrup } \\
\text { distance } 1\end{array}$ & $\begin{array}{l}\text { Stirrup } \\
\text { distance 2 }\end{array}$ \\
\hline $\mathrm{P}_{4}$. & Anchors & Anchor distance & Anchor depth & $\begin{array}{l}\text { Anchor } \\
\text { Dia. }\end{array}$ & Anchor length & - & - \\
\hline $\mathrm{P}_{5}$ & Bearing Walls & Wall thickness & Wall quality & $\begin{array}{l}\text { Connection to } \\
\text { column }\end{array}$ & $\begin{array}{l}\text { Connection to } \\
\text { beam }\end{array}$ & $\begin{array}{l}\text { Mortar } \\
\text { mix/quality }\end{array}$ & \\
\hline $\mathrm{P}_{6}$ & Ring Beam & Beam height & Beam thickness & Bar diameter & $\begin{array}{l}\text { Stirrup } \\
\text { diameter }\end{array}$ & $\begin{array}{l}\text { Stirrup } \\
\text { distance } 1\end{array}$ & $\begin{array}{l}\text { Stirrup } \\
\text { distance 2 }\end{array}$ \\
\hline $\mathrm{P}_{7}$ & $\begin{array}{l}\text { Concrete .roof } \\
\text { truss (hor. el.) }\end{array}$ & Beam height & Beam thickness & Bar diameter & $\begin{array}{l}\text { Stirrup } \\
\text { diameter }\end{array}$ & $\begin{array}{l}\text { Stirrup } \\
\text { distance } 1\end{array}$ & \\
\hline $\mathrm{P}_{8}$ & $\begin{array}{l}\text { Concrete .roof } \\
\text { truss (vert. el.) }\end{array}$ & Element width & $\begin{array}{l}\text { Element } \\
\text { thickness }\end{array}$ & Bar diameter & $\begin{array}{l}\text { Stirrup } \\
\text { diameter }\end{array}$ & $\begin{array}{l}\text { Stirrup } \\
\text { distance } 1\end{array}$ & \\
\hline $\mathrm{P}_{9}$ & $\begin{array}{l}\text { Concrete .roof } \\
\text { truss (incl.. el.) }\end{array}$ & Element width & $\begin{array}{l}\text { Element } \\
\text { thickness }\end{array}$ & Bar diameter & $\begin{array}{l}\text { Stirrup } \\
\text { diameter }\end{array}$ & $\begin{array}{l}\text { Stirrup } \\
\text { distance } 1\end{array}$ & \\
\hline $\mathrm{P}_{10}$ & $\begin{array}{l}\text { Concrete } \\
\text { pouring quality }\end{array}$ & Tie beam (TB) & Column (C) & $\begin{array}{l}\text { Ring beam } \\
\text { (RB) }\end{array}$ & $\begin{array}{l}\text { Roof truss } \\
\text { (vert. el.) }\end{array}$ & $\begin{array}{l}\text { Roof truss } \\
\text { (incl. el.) }\end{array}$ & \\
\hline $\mathrm{P}_{11}$ & Bar connection & TB-C.1 & TB-C. 2 & C-Truss (hor) & C-Truss (incl) & C-RB & \\
\hline $\mathrm{P}_{12}$ & Timber size & Wall beam wdt & Wall beam th. & Purlin width & $\begin{array}{l}\text { Purlin } \\
\text { thickness. }\end{array}$ & Peak beam & Peak beam th \\
\hline
\end{tabular}




\subsection{Interview and FGD}

Interviews were carried out to a number of parties during the emergency response, physical recovery and preparedness during and after a disaster. To maintain the validity of the results, the all collected information then to be evaluated, discussed and strengthened in the FGD. The

selected informant, topic, and information collected are presented in Table 3.

\subsection{Site and laboratory test}

Site measurement and tests were conducted simultaneously during the implementation of the physical recovery. Measurements were carried out involving all required physical data as presented in Table 2 including the on-site test of concrete quality by using non-destructed Hammer test. Meanwhile, the laboratory test was conducted to investigate the strength of concrete cylinder specimens. Results of Hammer will be used for verifying the results of the laboratory test.

\subsection{Secondary data}

The secondary data were collected from several sources particularly after the disaster. The data and information were collected from papers of the Proceeding Conference, Journals and general information from any media. Types of secondary data were used for checking, correcting and completing the required information. Since the investigation is spread out in the wide range of activities and because of the limitation of the space then only the most interesting information in every DM phase are presented in this paper.

\subsection{Method of analysis}

The data that have been collected are in the form of quantitative and qualitative information. The quantitative data related to width, thickness, height, length, diameter, distance, and strength. In ERS implementation all of those data have been standardized and clearly presented in the
Detail Engineering Design (DED). Thus, the analysis data was conducted by comparing the data with the existing standard. Meanwhile, the qualitative data were analyzed based on established theories, objective facts, and rational thought.

\section{Results and discussion}

\subsection{Early warning, the pyroclastic, and lahar flows}

The history of Merapi eruption has been identified since the $18^{\text {th }}$ century. According to [14] since 1768 the Merapi volcano has been experienced 49-times eruptions with return period is about 5 -years. Considering its frequent eruptions, Merapi volcano then becomes international volcano laboratory [15].

It is not wondering then Merapi volcano is instrumented for monitoring its activities. According to [16], Merapi activities have been monitoring through direct visual and instrumental observations. The instrumental observations are based on the records of seismology, geodesy, satellite Synthetic Aperture Radar (SAR) and gas measurements. The early warning system of Merapi volcano comprises of 4-levels. Level-I indicates the Merapi volcano is in the normal state without any tend in increasing activity. Level-II (alert) is intended whenever indicates in increasing the visual and seismic data. LevelIII (standby) is set up when there is a trend of increasing Merapi activity where a dangerous eruption may occur. Level-IV (beware) is the condition where the initial eruption is shortly to start. The visualization of early warning systems including the date, level and radius $\mathrm{R}$ $(\mathrm{km})$ for safety purposes is presented in Fig.2 [17].

According to $[18,19,20]$ the direction of the pyroclastic and lahar flows were $50 \%$ to the south-west (SW), $17 \%$ to South (S), $11 \%$ to West (W) and North West (NW), $6 \%$ to South-East (SE) and only $2,5 \%$ to Noth $(\mathrm{N})$

and east $(\mathrm{E})$. The visual direction of the pyroclastic and lahar flows of the Merapi eruption are presented in Figs.3 and 4 . The figures show that the pyroclastic and lahar of the Merapi eruptions mostly flowed to the south-west directions. As shown in Fig 5, the ordinate represents the

\begin{tabular}{|l|l|l|l|}
\hline No. & \multicolumn{1}{|c|}{ Informant } & \multicolumn{1}{|c|}{ Topic } & \multicolumn{1}{|c|}{ Information Collected } \\
\hline 1 & $\begin{array}{l}\text { Head of 2010 Merapi Eruption } \\
\text { Disaster Management }\end{array}$ & $\begin{array}{l}\text { The 2010 Merapi Eruption } \\
\text { and Disaster Management } \\
\text { (DM) }\end{array}$ & $\begin{array}{l}\text { General information on the 2010 Merapi Eruption Disaster } \\
\text { Management Implementation of the Early Warning, } \\
\text { Emergency Response in the Contingency Planning } \\
\text { The 2010 DM Achievements and Lesson Learned }\end{array}$ \\
\hline 2. & $\begin{array}{l}\text { Head of Preparedness and } \\
\text { Rehabilitation and Reconstruction } \\
\text { Division of Sleman Local Agency } \\
\text { of Disaster Management }\end{array}$ & $\begin{array}{l}\text { The Recovery and } \\
\text { sustainable Disaster Risk } \\
\text { Reduction (DRR) }\end{array}$ & $\begin{array}{l}\text { Implementation of the Recovery of the 2010 Merapi } \\
\text { Eruption Concept and implementation of sustainable DRR } \\
\text { The 2010 DM Achievement and Lesson Learned }\end{array}$ \\
\hline 3 & $\begin{array}{l}\text { The World Bank Disaster } \\
\text { Management Expert }\end{array}$ & $\begin{array}{l}\text { The 2010 Merapi Disaster } \\
\text { Recovery. }\end{array}$ & $\begin{array}{l}\text { The 2010 Merapi Eruption Physical Recovery } \\
\text { The 2010 DM Achievement and Lesson Learned }\end{array}$ \\
\hline 4 & $\begin{array}{l}\text { Evaluation, discussion and } \\
\text { strengthening results }\end{array}$ & $\begin{array}{l}\text { Additional DM Information and discussion } \\
\text { Strengthening and completing the 2010 Merapi Eruption } \\
\text { DM Achievement and Lesson Learned }\end{array}$ \\
\hline
\end{tabular}

Table 3. The informant, topic, and information collected 
maximum length $\mathrm{L}(\mathrm{km})$ of the pyroclastic and lahar flows. As long as can be traced by [14], Merapi has erupted 5times with VEI $=3$ i.e. in the year $1832,1846,1849,1930$ and 1962 ( 3-80 years return period) and 3-times with VEI $=4$ i.e. in year 1822,1872 and $2010(50-150$ years return period).

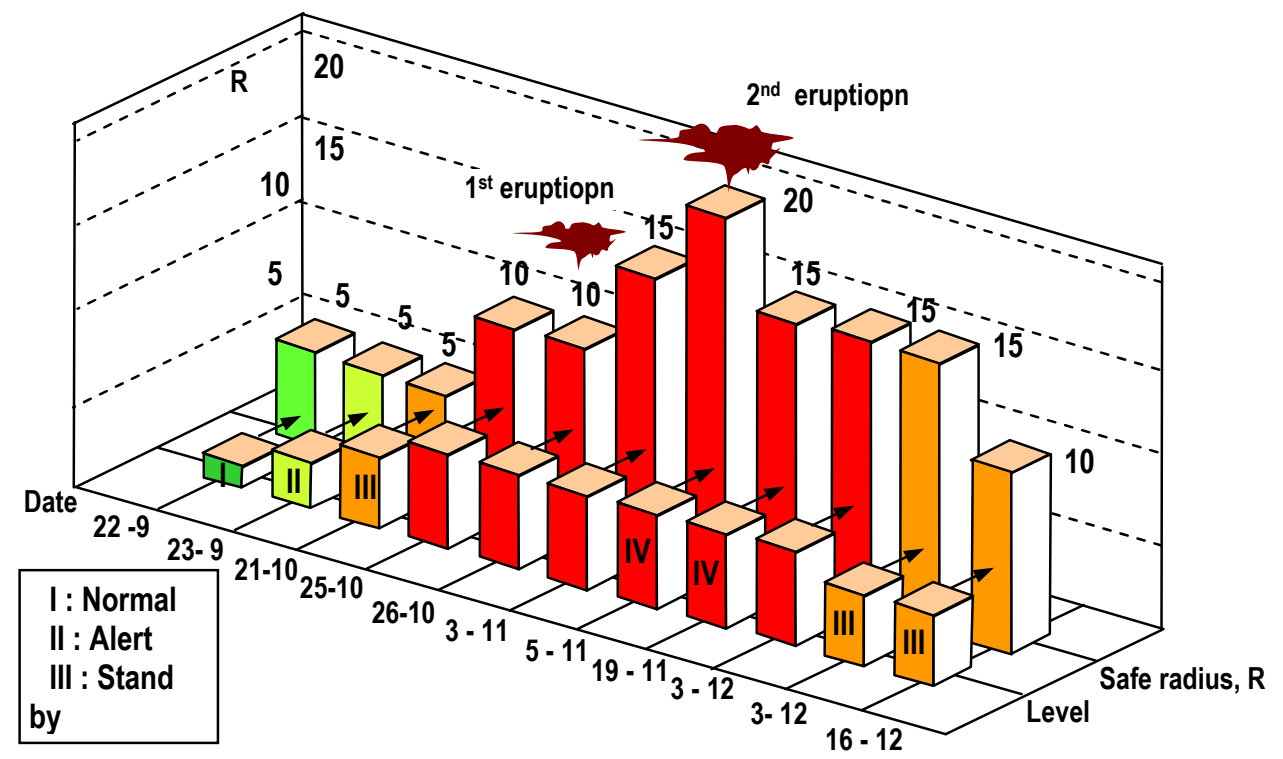

Fig. 2. The early warning visualization of the 2010 Merapi eruption.

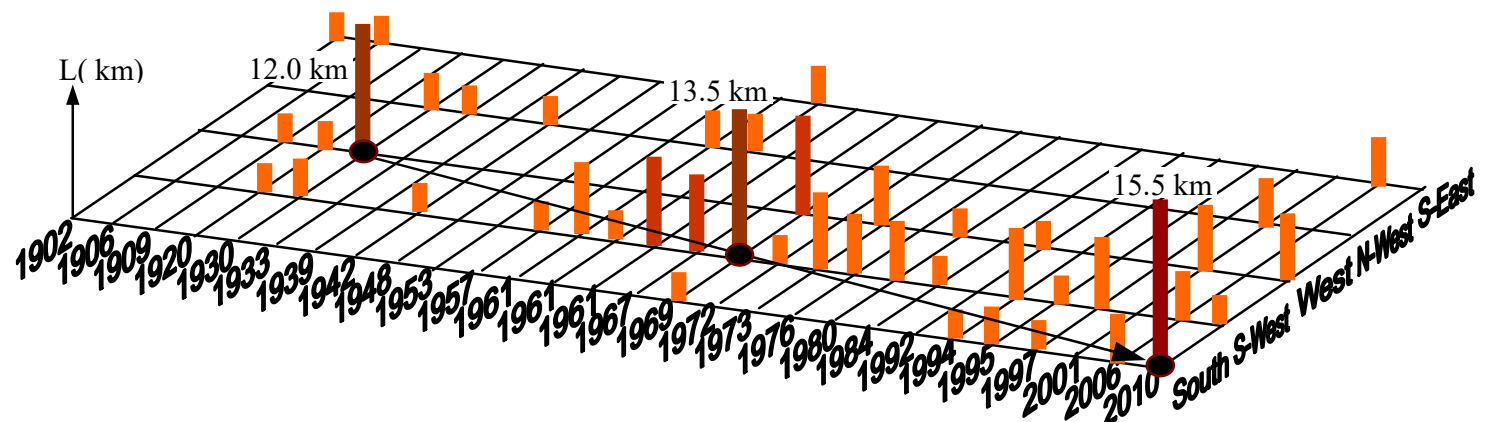

Fig. 3. The shifting direction of maximum pyroclastic and lahar flows.

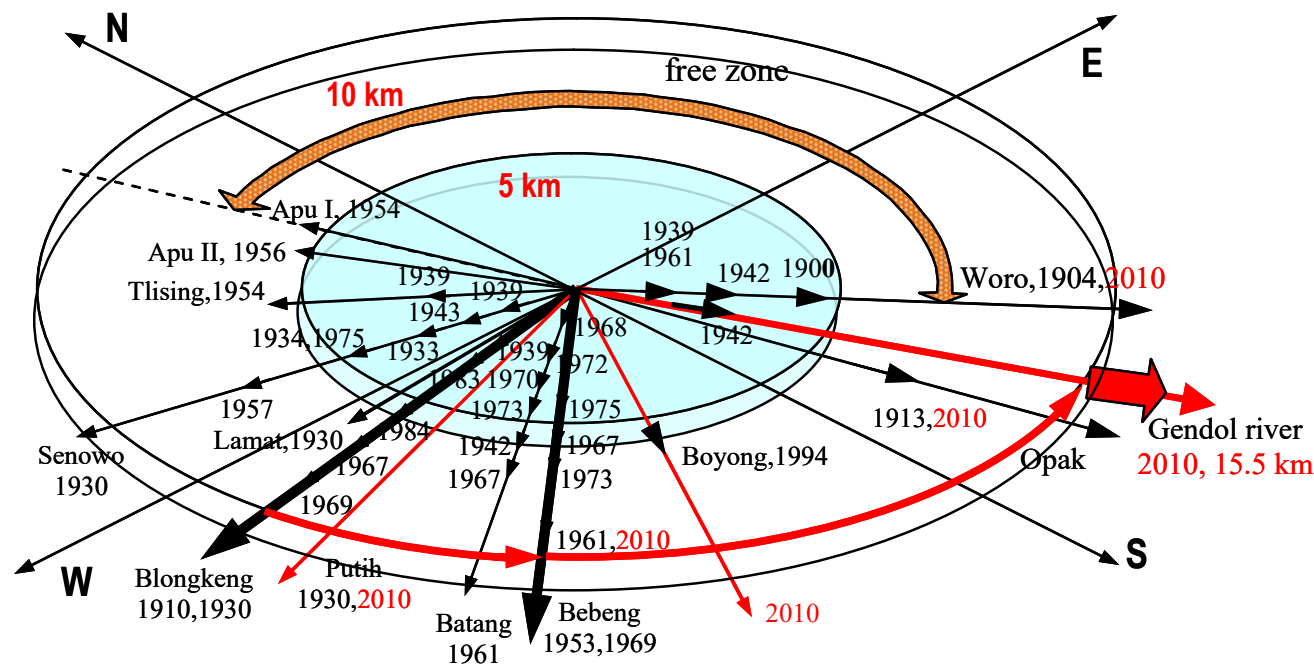

Fig. 4. History and shifting the pyroclastic and Lahar flow of the Merapi eruptions, mod. of [19] 
In Figs 3 and 4 also indicate that there have been shifted orientations of the dome failure followed by the pyroclastic flows from West (1930 with 1369 casualties) to South-West (1969 only 3 casualties) and finally to South direction (2010 with 386 casualties). The maximum lahar flow's length L $(\mathrm{km})$ was likely also increased from $12 \mathrm{~km}$ in 1930 into $13.5 \mathrm{~km}$ in 1969 and became $15.5 \mathrm{~km}$ in 2010 . The different directions of pyroclastic's flows as compared to the previous events becomes one of causing high fatalities in the 2010 Merapi eruption.

\subsection{Distribution of housing collapsed and fatalities}

The affected area of the 2010 Merapi eruption covers the Magelang, and Boyolali districts for Central Java Province and Sleman district for Yogyakarta Special Province. There are 17-districts in Sleman, however only three-subdistricts in Sleman which are directly adjacent to Merapi volcano i.e. Turi, Pakem and Cangkringan sub-district. In further Cangkringan sub-district consists of Umbulharjo $(\mathrm{U})$, Kepuharjo (K), Glagahharjo (G), Wukirsari (W) and Argomulyo (A) sub-district such as shown in Figs. 7 and 8

According to data issued by The National Agency for Disaster Management by $19^{\text {th }}$ November 2010 the housing totally collapse were more than 2330 units, however, the final data by $31^{\text {st }}$ December 2010 the housing collapsed were more than 3000 units. The housing collapsed were more concentrated in the most devastated area which consists of 5 sub-district. The major housing collapsed occur in Unbulharjo (U), Kepuharjo (K) and Glagaharjo (G) sub-district, where another 2 sub-district occurred in Wukirsari (W) and Argomulyo (A). The distribution of the housing collapsed is presented visually as depicted in Fig.5. As shown in the figure that the direction of pyroclastic and lahar follows the flow of Gendol river with the orientation to south direction. The typical damage or collapse of the houses mainly caused by burned by extremely high temperature, collapsed by the dynamic pressure of pyroclastic blasting and collapsed by quasidynamic force of lahar flow.

Meanwhile, the distribution of the casualties is presented visually in Fig. 6. Prominently the victims were caused by two major eruptions i.e. eruption at 26th October 2010 and eruption at past mid-night of 5th November 2010. The Centre for Volcanology and Geological Hazard Mitigation (CVGHM) located at Bandung, Indonesia is a government institution which is responsible for carrying out of monitoring and assessing of volcanic activities in Indonesia. In the case of Yogyakarta, the monitoring of Merapi activity is conducted by The Institute for Research and Technology Development of Geological Disaster (BPPTKG) under the coordination of CVGHM Bandung.

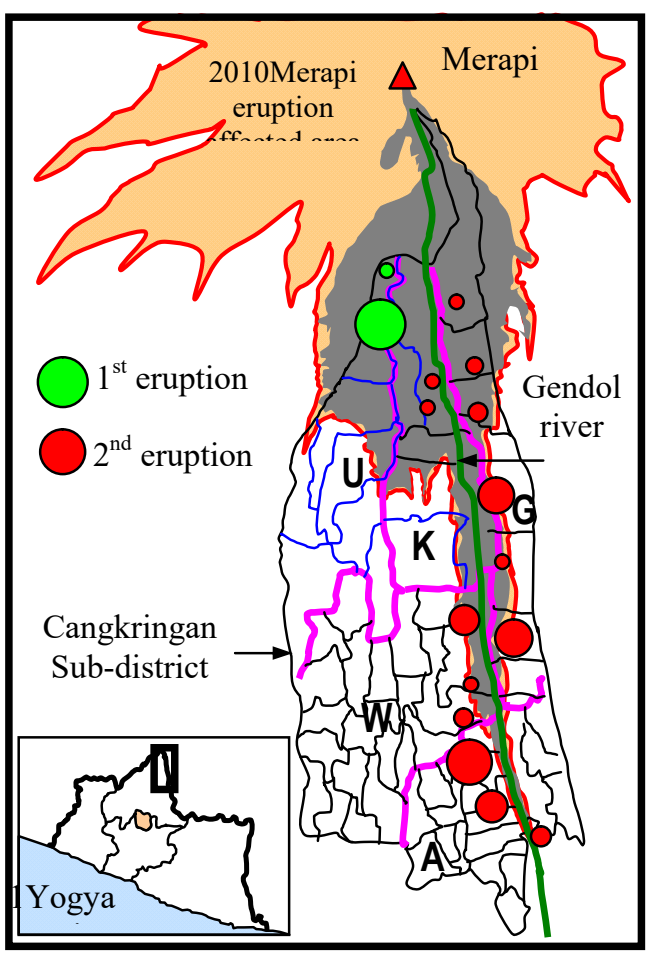

Fig. 6. Fatalities distribution map 
The long sequential development of Merapi early warning was presented by [16]. However, long story cutting too short, in the 25 October 2010 evening, the Level-III was raised to be the highest level i.e. Level-IV (Beware) in which the high probability of large explosive eruption may occur. In Level-IV, the action was to call for massive evacuation of several tens of thousands of peoples within a region extending a radius of $10 \mathrm{~km}$ from the Merapi summit. Indeed, the first 2010 Merapi eruption occurred only 23 hours after the Beware was issued that was $26^{\text {th }}$ October 2010 in the afternoon time.

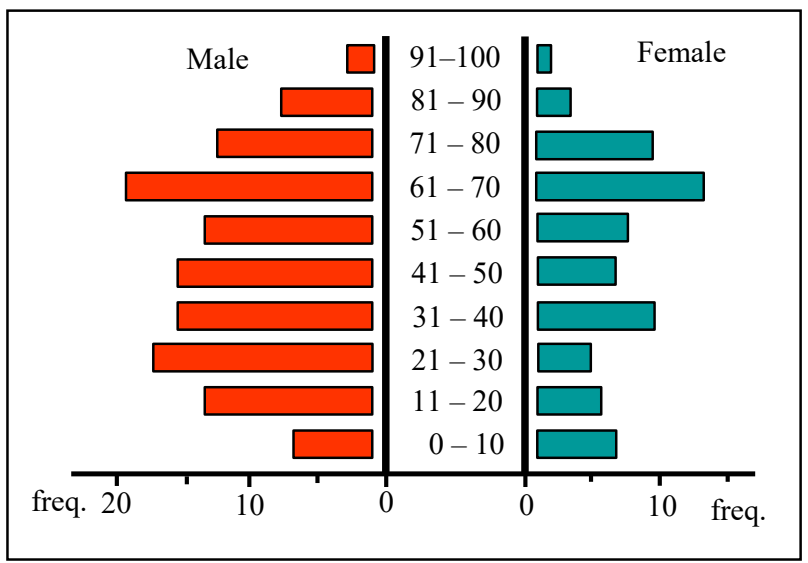

Fig.7. The distribution of gender and age of the casualties

The people severity of the 2010 Merapi volcano natural hazard started after the first eruption has occurred. It has been issued by media and as presented by [6] that at immediately time before eruption the Local Authorities, Medical Teams, and the Volunteers have already persuaded the Marijan grandfather at Kinahrejo village (Marijan is the spiritual Merapi gatekeeper) and his followers to be evacuated went down. However, many residents were reluctant to leave their village. Finally, they

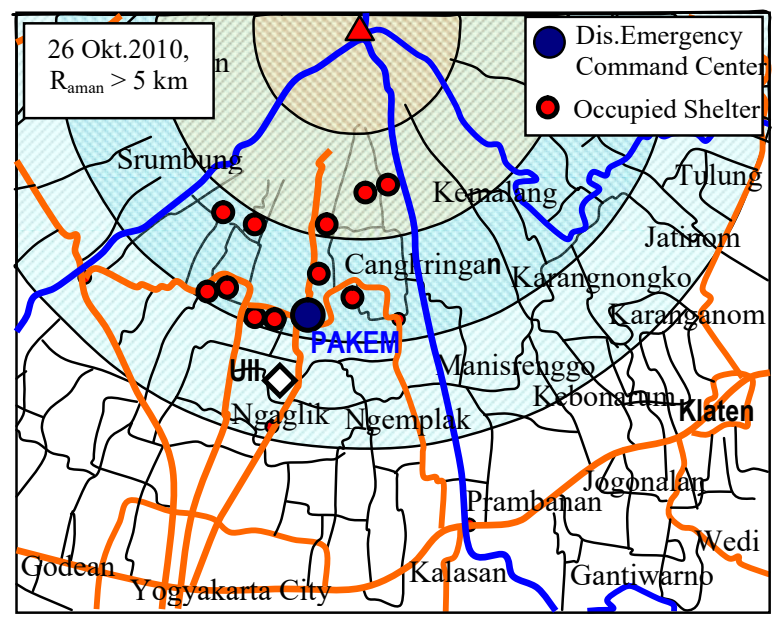

Fig. 8. Refugee and shelters before $21^{\text {st }}$ Oct. 2010 were 34 peoples became the victims of Merapi violent. The casualties are presented in the 1st eruption in Fig.8.

Another case has happened at the Bronggang village at Argomulyo sub-district. Between 26th October to 4th November 2010, the evacuation continuously carried out. However many male people at the day and the night time prefer to return back to their house according to several reasons (boring stayed at the shelter, to take care their livestock, plantations and any business). The result of the interview indicated that actually the village officials already reminded them to back to shelter particularly at night time. However, they assumed that the Merapi would not further be erupted and if erupted, the effects would have flowed to the west directions like as usual. At the past mid-night 5th November 2010, the pyroclastic waves of the $2^{\text {nd }}$ eruption of the Merapi flowed to south direction. A number of 233 people died in the 2nd eruptions. Distribution of the fatalities is presented in Fig. 8. Meanwhile, the gender and the age distribution of the victims are presented in Fig.7.

\subsection{The Merapi 2010 emergency response and disaster management}

The disaster emergency response actually is only the implementation of the Disaster Contingency Plan. The disaster Contingency Plan covering a lot of activities such as presented by [21] for volcanic disaster or by [22] for earthquake disaster. Contingency plan itself can be defined as an organized and coordinated set of steps to be taken in an emergency strikes. Investigation of the emergency response was carried out when the refugees were placed at Maguwoharjo Sports Stadium after the large explosion on 5th November 2010. Actually, a lot of stories can be described and discussed. Again, because of the limitation of time and space only the history of the refugee movements in Sleman Regency is presented.

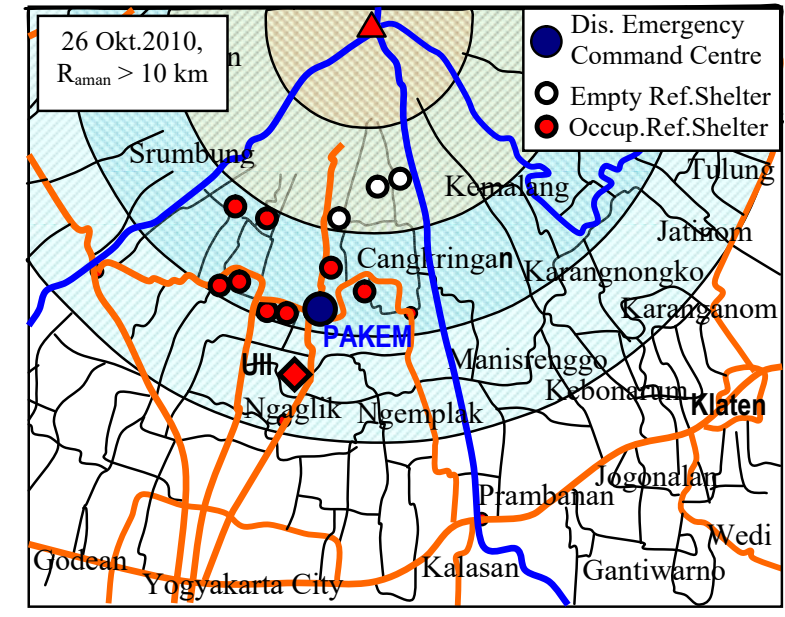

Fig. 9. Refugee and shelters after $25^{\text {th }}$ Oct. 2010 
As shown in Fig. 8, the refugees stayed at shelters within the safe radius $\mathrm{R}<10 \mathrm{~km}$ before 25th October 2010. The disaster Emergency Command (DEC) was located at Pakem. After the 1st eruption on 26th October 2010 , the refugees should be moved to the more safe places i.e. on the radius $\mathrm{R}>10 \mathrm{~km}$ as presented in Fig. 9, where the DEC was still in Pakem. However, after Merapi activity tends to increase than refugees should be moved again to the more safe shelters on 3rd November 2010 i.e. in the safe radius $\mathrm{R}>15 \mathrm{~km}$. the Islamic University of Indonesia just located at $17 \mathrm{~km}$ away from Merapi summit and The University Sports Centre became one of the refugee camps. When the Merapi activity close to the 2 nd eruption on 5th November 2010, the refugees were called to move to more safe place i.e. within the safe radius $\mathrm{R}>$ $20 \mathrm{~km}$ as presented in Fig. 10 including refugees at UII Camp. Finally, the refugees were accommodated at Maguwoharjo Sports Stadium and any other places. The schedule of the refugee movement is presented in Fig. 11.

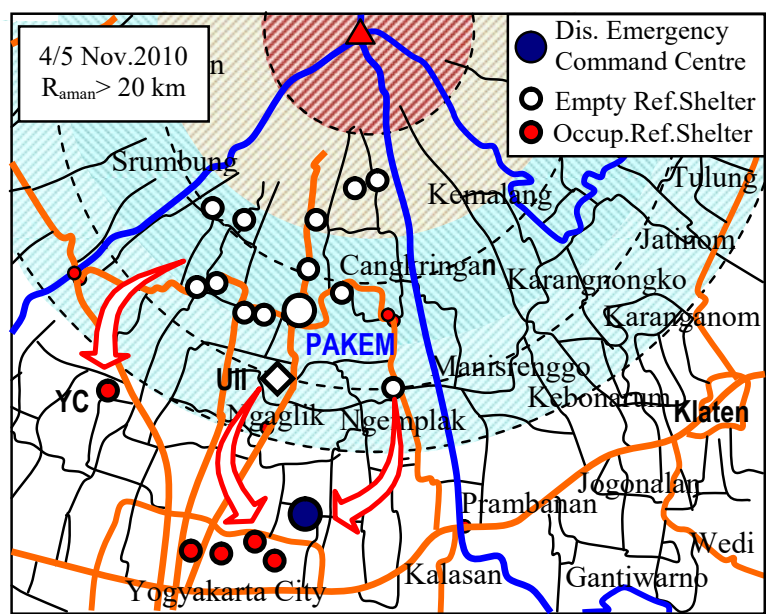

Fig. 10. Refugee and shelters after $3^{\text {rd }}$ Nov. 2010

\subsection{The Merapi 2010 physical recovery}

The Merapi recovery was carried out in 2-phases i.e. through temporary shelter program and permanent resettlement. The elevation and map of the Merapi resettlement are presented in Figs.12 and 13. It can be identified from Figs 12 and 13 that the permanent resettlements were still located close to Volcano Hazard Zone II (VHZ-II). This decision was determined according to a common strong requirement by beneficiary i.e. the locations of the resettlement are required not too far away from their initial village. By considering this requirement, the locations of permanent resettlement were located relatively close to VHZ-II. According to Merapi Recovery Plan (RENAKSI Merapi), the VHZ-II is the area with a possible medium probability of risk. Accordingly, the people are strongly required to be evacuated whenever increasing of Merapi activity is detected. The building of disaster community resilience is obligatory in this area.

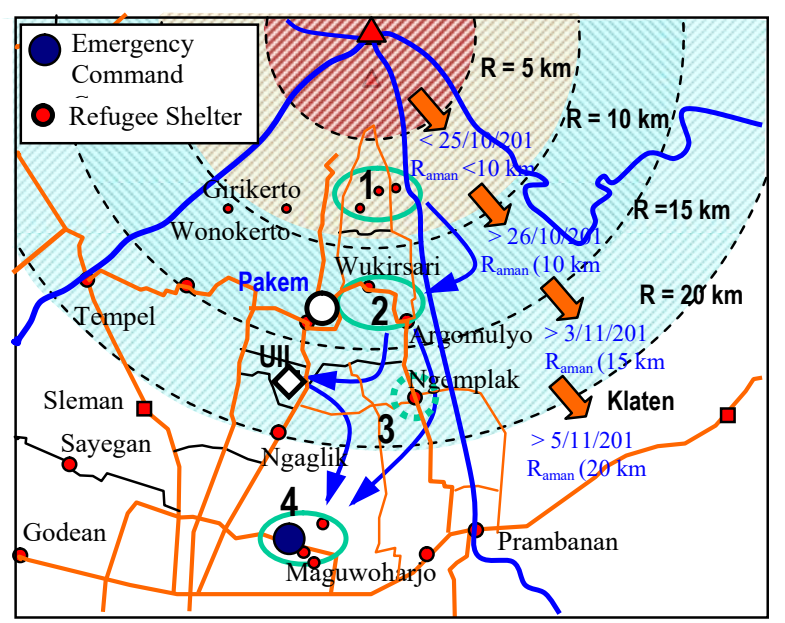

Fig. 11. Refugee and shelters after $5^{\text {th }}$ Nov. 2010

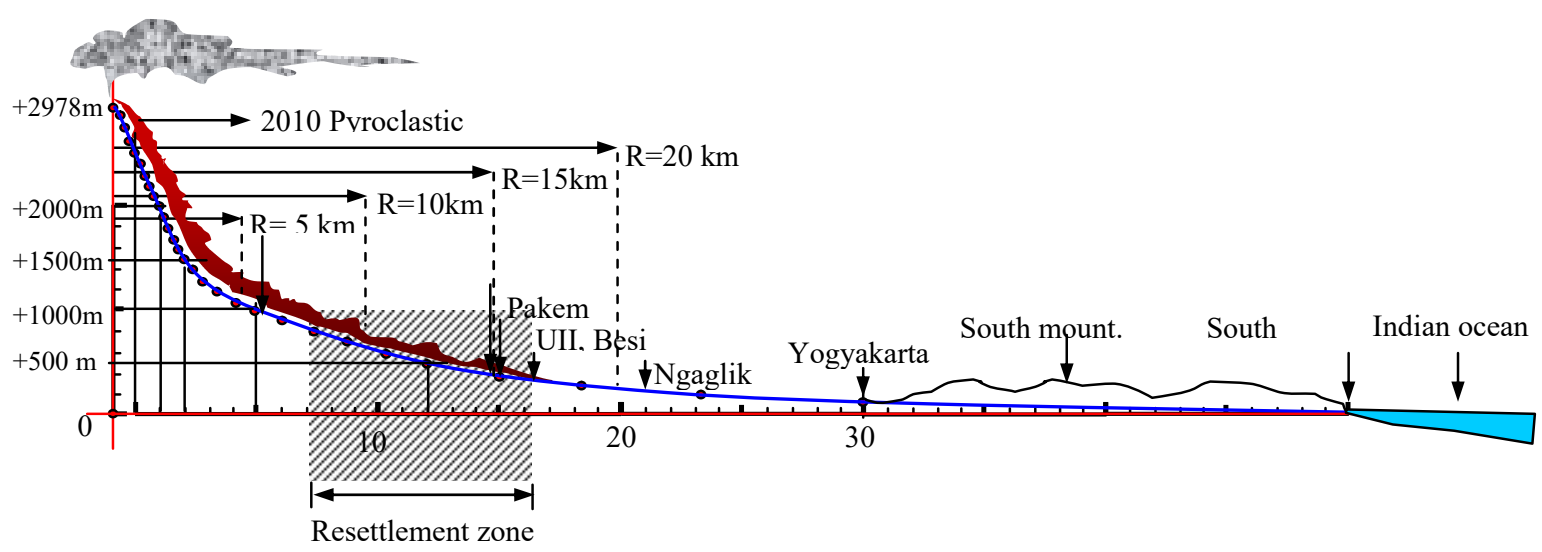

Fig. 12. The elevation of the Merapi resettlement 
Table 4. Reconstruction strategy and implementation

\begin{tabular}{|l|l|l|}
\hline No. & Strategy for Disaster Recovery & \multicolumn{1}{|c|}{ Reconstruction implementation } \\
\hline 1 & Building Back Better (BBB) & Earthquake resisting housings were constructed \\
\hline 2 & Engage and train local communities & Technical assistance in constructions was carried out \\
\hline 3 & Focus on permanent, not temporary solutions & Permanent housing was constructed \\
\hline 4 & Respect local sustainability practices & - \\
\hline 5 & Address ecosystem and socio/cultural issues & $\begin{array}{l}\text { Reconstruction starts with the most vulnerability } \\
\text { family }\end{array}$ \\
\hline 6 & Use an integrated design process & Housing design according to community participation \\
\hline 7 & Aim to restore local economies quickly & Economic recovery is also under the recommendation \\
\hline 8 & $\begin{array}{l}\text { Integrate advanced technologies with locally } \\
\text { available resources }\end{array}$ & $\begin{array}{l}\text { Reconstruction was carried out mostly by using local } \\
\text { materials }\end{array}$ \\
\hline 9 & Keep the implementation plan simple & - \\
\hline 10 & $\begin{array}{l}\text { Communicate best practices and ensure access } \\
\text { to information for all stakeholders. }\end{array}$ & $\begin{array}{l}\text { The transparency in the rehabilitation and reconstruction } \\
\text { was adopted and implemented }\end{array}$ \\
\hline
\end{tabular}

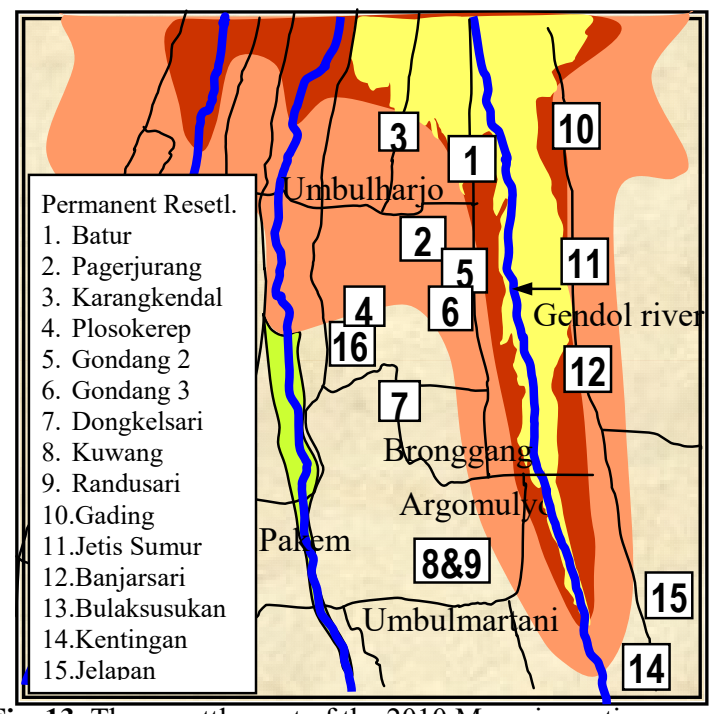

Fig. 13. The resettlement of the 2010 Merapi eruption

Meanwhile, Table 4 is the implementation of the reconstruction strategy according to Canadian Response Model (CR Model) proposed by [10]. As shown in Table 4 that almost all aspects of the CR Model were consistency implemented. Similar as presented before, the implementation of disaster recovery is also a long story/way. In this paper, the only more technical aspect of disaster recovery is presented i.e. the construction of earthquake resistant structure (ERS).

The parameter and indicators of ERS are presented in Table 2 and the measured parameter from the site are presented visually in Fig.14. The implementation of ERS covers 12 parameters and 48 indicators. The numerical indicator $100 \%$ means that the diameter, distance, quality, width, thickness or length installed in the construction site is exactly as required by the standard. It was found that the average value of the numerical indicator is $98.98 \%$ (close to $100 \%$ ). Meanwhile, mean concrete compressive strength results from 133 Hammer test and 27 specimens of laboratory tests are $21.12 \mathrm{MPa}$ and $17.71 \mathrm{MPa}$ respectively. The results are still higher than the minimum concrete compressive strength of 17.5 $\mathrm{MPa}$ according to
SNI 2847,2000. Thus, it can be concluded that the housing construction quality of the 2010 Merapi eruption has fulfilled the requirement of ERS.

\subsection{The achievements and lesson learned}

\subsubsection{Disaster management achievements}

Achievements and Lesson Learned during the Merapi 2010 disaster management are the major findings of this study. The achievements started from the disaster early warning, disaster prediction, disaster Search, and Rescue, (SAR), Disaster emergency response as well as during the disaster recovery.

\subsubsection{Disaster monitoring and Early Warning (EW)}

According to [14] the deformation anomaly to the south direction (Kaliurang station to Merapi summit) was detected since November 2009. None anomaly deformations were detected in the north and north-west directions. The history, status and its corresponding safe radius $\mathrm{R}(\mathrm{km})$ of Merapi activity are presented in Fig.4. The monitoring and EW of the Merapi activity have been well done [23] and followed by action executions in the critical time. These results are appreciated and to be one of the government achievement in the Merapi Disaster management.

\subsubsection{Merapi eruption Prediction}

It was clearly stated by [16], that after the seismicity and deformation increased dramatically, on 25th October 2010 at 18:00 local time, the Merapi status was raised to the highest level i.e. to Level-4. The condition has reached on the high probability of a large explosive eruption. That was a perfect prediction, on 26th October 2010 at 17:02 local time Merapi erupted, it was only 23 hours after the critical declaration of Level-4. This was a prominent government achievement in the Volcano Disaster Risk Reduction. 

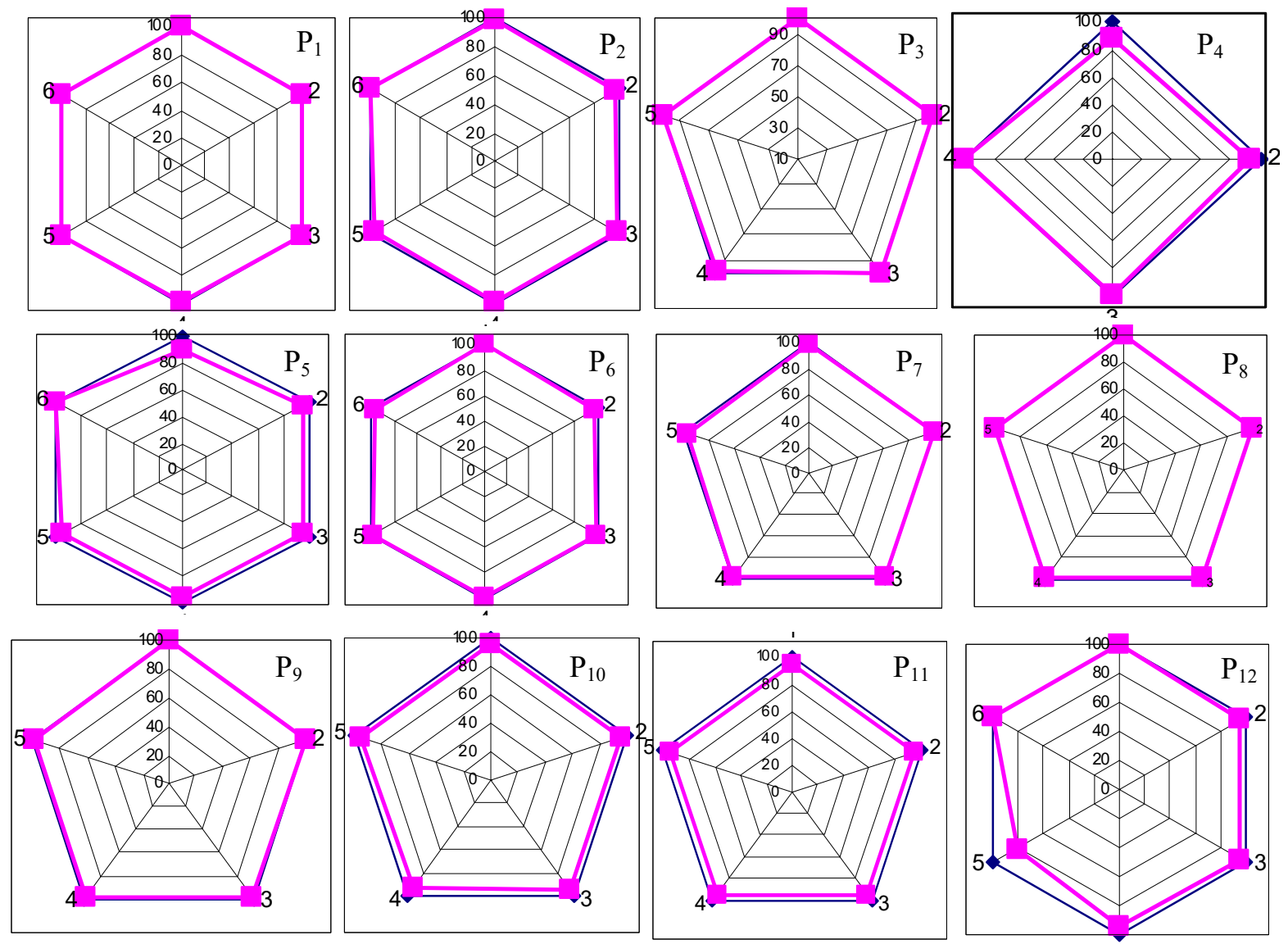

Fig. 14. The measured indicators based on field investigation

\subsubsection{Refugee evacuation}

Refugee evacuation data indicated that on the 25th October 2011, not more than 22500 people had to be evacuated from their house, shelters to more safe shelters. It was not a simple duty; the refugee evacuation is even a complex task [6]. Although different from those reported by [24], evacuation of the refugee has been successfully conducted. Report as presented by [25], indicated that self-help in the evacuation was $55 \%$ (37\% by motor-cycles and $18 \%$ by personal cars) and $42 \%$ by using buses and trucks. The community participation during evacuation was great, this is another achievement

\subsubsection{Charismatic leader}

The Governor of Yogyakarta Special Province (YSP) is the King and also Sultan of Yogyakarta. As a Leader and King of YSP, the Governor becomes role models, keeps the customs, cultures, and religions and have the charisma to make what he said is obeyed by people of YSP. This condition is very helpful particularly of his command to solve the problem during critical emergency condition.

\subsubsection{Transfer of land policy}

The area of the YSP is really not wide as to compare with other provinces in Indonesia. Therefore, to provide land for resettlement of 2010 Merapi eruption victim is clearly not easy. State land in Yogyakarta is very limited, the available land is only "Village Cash Land". By this fact, the Governor of Yogyakarta takes the right and quick decision/policy that are by transferring the Village Cash Land to the land of resettlement. This policy or decision is highly appreciated and makes the rehabilitation and reconstruction of 2010 Merapi victims run smoothly and quickly.

\subsubsection{Disaster recovery}

According to the data released by World Bank, housing collapsed under the 2010 Merapi eruption at Yogyakarta and Central Java reached more than 3000 units, among them 2083 unit occur at Yogyakarta. According to BNPB, 
the Merapi recovery was planned only during 2-years (2011-2013). It should be noticed that beneficiaries actively involved booth in the planning and housing construction. This is an implementation of the community participation as presented in the 2010 Merapi Recovery Plan. Community participation was able to speed up the reconstruction process. This is also the important achievement of the Merapi Disaster recovery.

\subsubsection{Lesson learned}

Aside of achievements, several lessons learned have been identified. The lesson learned was formulated based on the real implementation of the 2010 Merapi disaster management. The corresponding lesson learned is in the following items.

\subsubsection{Modern/scientific support (prevention phase)}

Marijan grandfather was spiritually/traditionally gatekeeper of Merapi which was appointed by the late of Hamengkubuwono IX (HB IX), the King of Yogyakarta. The knighthood character is tightly attached to his personality. By considering his position, he believed that fighting with volcanic threat is one of the gate-keeper responsibilities, no retreat in facing the risk whatever it would be. By keeping his spiritual/cultural faith, he bravely stayed in his house on 25th October 2010 evening and finally he was to be the victim of the violence of Merapi eruption. Lesson learned from this event is that in the future the traditional belief as embraced by Marijan grandfather should be supported by scientific knowledge. The name of Marijan grandfather now has been tightly adhered on the people's mind as a legend of the Merapi volcano.

\subsubsection{Tell story (early warning phase)}

During the 2010 Merapi eruption, the information received by the community during early warning phase mostly was informed by TV media, radio, newspapers or websites. By this condition the coverage and frequencies of information issued strongly affected by the journalist. Basically, the community has a right to receive regular information from the government relates to the development of a potential hazard. Therefore, the lesson learned from this phase is that in the future the government should officially be carried out a regular broadcast on TV media, radio or presents any regular information to the community by using any types of media.

\subsubsection{Safe distance $r$ (evacuation phase)}

In the early development of increasing Merapi activity, the evacuation of the people was based on the Merapi Hazard Map (MHM) for instance evacuation from MZM-III to
MHM-II. However, after the activity of Merapi reached Level -IV, calling for people's evacuation was based on the distance of their villages to the Merapi summit. This distance so called the safe radius $\mathrm{R}$, for example, 10, 15 and $20 \mathrm{~km}$. However, the signed distance R from the Merapi summit has not been installed at their villages. The community confused and there was a big question how long is the distance of their village to the Merapi summit. Lesson learned from this event is that the early warning should be understandable by the community.

\subsubsection{Care and discipline}

The first eruption of Merapi on October 26, 2010, has been well predicted and evacuation of people has been done as well. People who live around the Gendol river are ordered to evacuate primarily at night. Many people living in their homes became victims of the midnight violence of the Merapi eruption on the 4th November 2010 due to disobedient and undisciplined instructions of the officers. Based on this tragic experience, care and discipline should be taken in facing of the natural hazards.

\subsubsection{Public Relation (PR) Com. (Em. Response phase)}

During the emergency response, a lot of food materials were required for refugee consumption. The food materials can be bought from any market. Actually, a lot of group of people wanted to support the availability of the food material. However, because of no clear information about what the food materials were urgently needed, sometimes a group of people dropped any food materials that really still under-stock, but lack any particular food material in another side. Personally, there were a lot of people in the community supposed to participate in providing foods or clothes, but they did not know where their helping should be submitted. Thus, the lesson learned in this condition is that in the future the Disaster Public Relations section should be well prepared.

\subsubsection{Capacity building of craftsman}

The 2010 Merapi recovery plan for permanent resettlement targeted only for 2-years (2011-2013). The time was allocated for determining the resettlement area, preparing the land, infrastructure, and housing construction. As previously mentioned that in the recovery program, it should be constructed more than 2000 housing units at the corresponding period. The housing construction was really conducted in the massive program in a relatively short time. Lesson learned from this stage is that in the future, the building craftsman skills should be well prepared to more improve the quality of the reconstruction. 


\subsubsection{Buffer boundary}

Theoretically, the boundary between Disaster Prone Area III (KRB III) and KRB II is only presented by line. Line borders produce problems in the field because drastic changes between forbidden and permitted area in the field are difficult. Although the border is presented by the line, to keep the settlement safe, in the future a buffer limit between 2-KRB should be implemented.

\subsubsection{Comprehensive contingency planning}

According to existing data, the last VEI-IV of the Merapi eruption was in 1930. Since 1930, the spatial impact of the Merapi eruption is so wide that the Contingency Plan that exists including refugee shelters focuses only on an area about $5 \mathrm{~km}$ from the peak of Merapi. The pyroclastic flow from the 2010 eruption even reached approximately $16 \mathrm{~km}$ from the summit. The lesson of this fact is that in the future the Merapi Contingency Plan should cover a wider radius range.

\subsection{The sustainable volcano disaster risk reduction}

As presented before that there are 3-pillars in sustainability i.e. sustainability in social, environmental and economic.
There are a lot of parameters and indicators involve in the sustainability. The only social pillar will be discussed in the paper particularly on the education and building community resilience efforts in disaster risk reduction. The disaster risk-reduction though education was recommended at the 3rd priority of actions in The Hyogo Framework for Action (HFA) 2005-2015. Meanwhile, the building community resilience to disaster risk reduction was clearly stated in 4th priority in The Sendai Framework Disaster Risk Reduction (SFDRR) 2015-2030.

The continuation of the education innovation is developing disaster resilience sister schools. It means that the either ordinary or resilience schools in the most probable affected area (inside sister schools) are connecting to the similar level's schools at outside (outside sister schools) of the most dangerous area as their sister schools. Whenever it will be a volcanic eruption in the future, the outside sister schools are welcome to receive their sister from inside sister schools. The scenario of the joining sister schools is presented in Fig. 16.

Further innovation also has been developed i.e. by developing disaster resilience villages. The locations of the resilience village are presenting in Fig. 17. As shown in the figure that villages near the Merapi summit are designed to be a volcanic resilience and the other is intended to earthquake and landslide resilience villages. Similar to

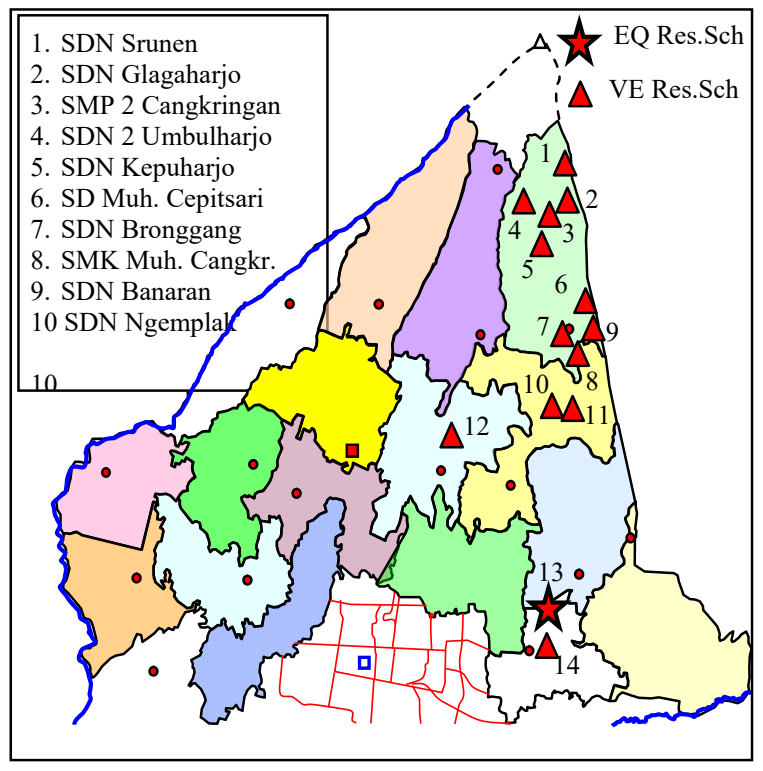

Fig. 15. Resilience school map

sister schools, it was also developed sister villages with the scenario of people evacuation as presented in Fig.18. In the figure shows that the scenario of people evacuation among the sister villages is designed according to the river flow area and the safe distance $\mathrm{R}(\mathrm{km})$. The resilience schools, resilience villages, sister schools and sister villages are desired to be a system in disaster risk reduction

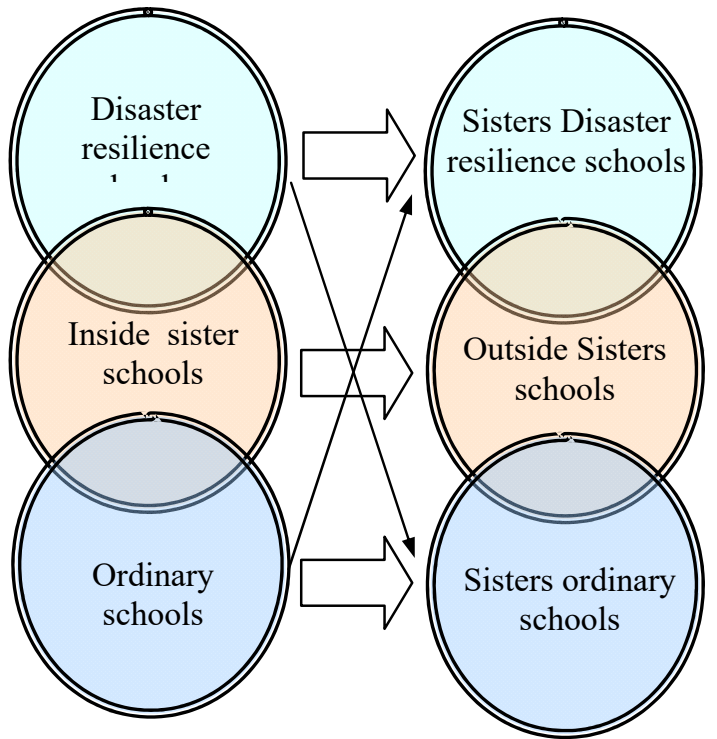

Fig. 16. The concept of sister schools sustainability. Due to the limitation of the time and space, the economic and environmental sustainability are not presented in this paper. 


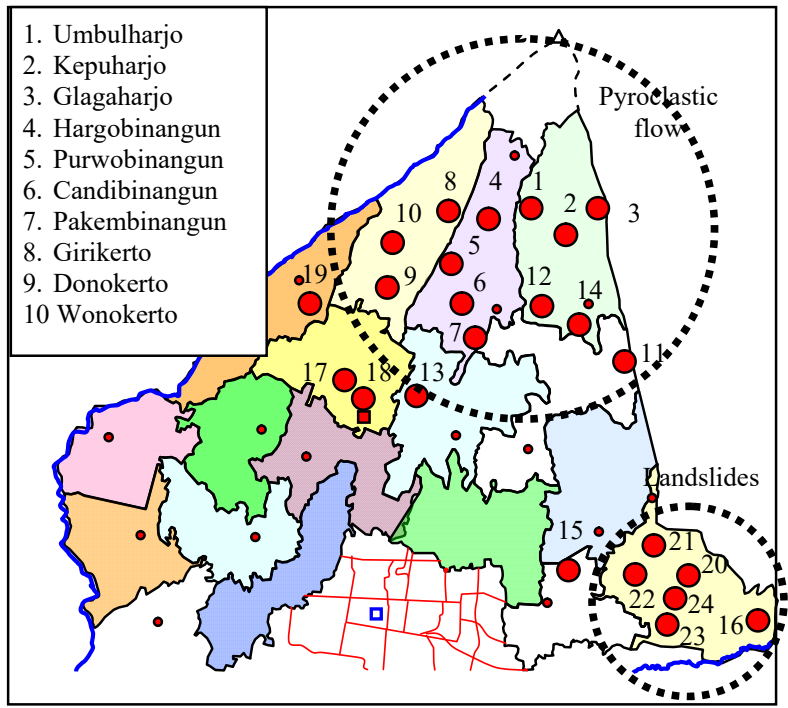

Fig. 17. Resilience village map

\section{Conclusions}

In general, the implementation of disaster management in volcanic hazard in Yogyakarta, Indonesia has been applied appropriately. The implementation covers all phases of the disaster management. Due to the limitation of time and space, only part of the early warning, disaster emergency response, and disaster recovery are presenting in this paper. In addition, the basic concept of sustainable disaster risk reduction is also presented. Scopes of this study are still relatively wide and tend to be an assessment study, therefore, narrower and deeper studies are strongly required in the future. Based on the study as presented, the following conclusion can be drawn:

1. There has been shifting in dome collapsed orientation, pyroclastic and lahar flow directions from the most often to South-West to South direction. This shifting orientation caused heavily damage of housings, environments as well as the number of fatalities,

2. Several achievements in the implementation of the 2010 Merapi eruption have been gained. Those achievements are clear monitoring of Merapi activity, successfulness of the Merapi eruption prediction and refugee evacuation as well as developing community participation and construction quality during disaster recovery,

3. The quality of disaster management, however, still needs to be improved. The improvement can be done by considering several lessons learned as presented in Section 7.5.2. It was found that the implementation of housing construction and material qualities in the site fulfilled the requirement of ERS,

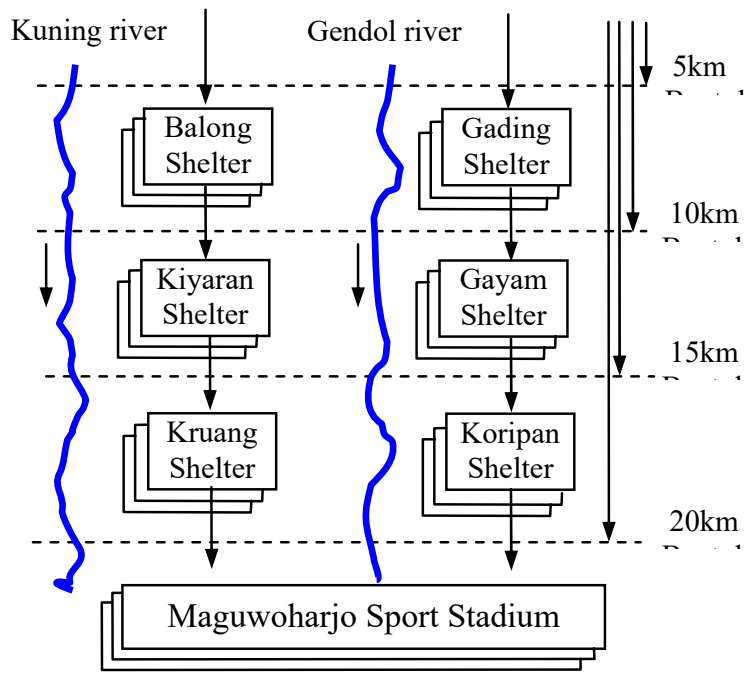

Fig. 18. Scenario of evacuation

4. Base on the experience during the emergency response, an innovation on the education was made i.e. by launching the resilience schools and sister schools. Building resilience schools are intending to make the disaster risk reduction become sustain as clearly stated in the 3rd priority in [3],

5. Another innovation is developing resilience village as well as sister villages. By developing sister villages, the evacuation of refugees in the future can be carried out with more flexible.

\section{References}

1. Lindel M K, (2010), Recovery and reconstruction after the disaster, Encyclopedia of Natural Hazards, Springer, (2001)

2. The United Nation website [Online], Available at: http://www.un.org/womenwatch/ods/A-RES-601-E.pdf, (2005)

3. The International Strategy for Disaster Risk Reduction (ISDR) website [Online], Available at www.unisdr.org, (2005)

4. The International Strategy for Disaster Risk Reduction (ISDR) website [Online], Available at: https://www.unisdr.org/files/43291_sendaiframew orkfordrren.pdf, (2015)

5. Mei E T W, Lavigne F, Picquout A, de Balizal E, Brunstein D, Grancher D, Sartohadi J, Cholik N, Vidal C, Lesson learned from the 2010 evacuation at Merapi volcano, J. of Volc. and Geothermal Research, 261(-), pp.348-365, (2013) 
6. Iguchi $\mathrm{M}$, Ishihara $\mathrm{K}$, Surono, Hendrasto $\mathrm{M}$, Learn from 2010 eruptions at Merapi and Sinabung volcanoes in Indonesia, Annuals of Disas.Prev.Res.Inst., Kyoto University, paper No.54B, p.185, (2011)

7. Mei E T W, Fajarwati A, Hasanati S, Sari I M, Resettlement following the 2010 Merapi Volcano eruption, Procedia-Social, and Behavioral Sciences, 227(-), pp.362-369, (2016)

8. Depari C D A, Sustainability and Vulnerability: Understanding the anomaly from Disaster Perspectives. Case study : Glagaharjo Village in Mount Merapi, $3^{\text {th }}$ International Conference on Planning in the Era of Uncertainty,Earth and Environmental Science 70 (012035), (2017)

9. Otani K, Legono D, Darsono S, Suharyanto, Effects of Disaster Management Programs on Individual's Preparedness in Mount Merapi, J. of Civil Eng. Forum, Vol.4, No.1, pp.79-89, (2018)

10. The Canadian Response website [Online], Available at : http://sbcanada.org/wpcontent/uploads/ 2015/02/ SBC_Reconstruction Charrette Final.pdf, (2006)

11. BNPB, BAPPENAS, Rehabilitation and Reconstruction Action Plan after the Mount Merapi Eruption Disaster, D.I Province of Yogyakarta and Central Java, 2011-2013, National Disaster Management Agency (BNPB), (in Bahasa), (2011)

12. Kuhlman T, Farrington J, What is sustainability?, Sustainability 2(-), pp.2426-3448, doi : 10.3390/su2113436 (2010)

13. Baird $M$ E, The Phases of Emergency Management Inter-modal Freight Transportation Institute, University of Memphis, Report January, (2010)

14. Voight B, Constantine E K, Siswowijoyo S, Torley R, (2010), Historical eruptions of Merapi volcano, Central Java, Indonesia, 1768-1998, J. of Volc. and Geothermal Research , 100(-), 69-138, (2000)

15. Jousset P, Pallister J, Surono, The 2010 eruption of Merapi volcano, J. of Volc. and Geothermal Research, DOI: 10.1016/j.jvolgeroes.2013.05.008, (2013)

16. Surono M, Jousset $\mathrm{P}$, Pallister J, Boichu M, Buongiorno F M, Budisantoso M, Rodriguez S C, Andreastuti S, Prata F, Schneider D, The 2010 explosive eruption of the Java's Merapi Volcanoa 100 years event, J. of Volc. and Geothermal Research, Elsevier 24-242, pp. 121-135, (2012)
17. Widodo P, Implementation of the 2010 Merapi Eruption Disaster Emergency Response in Sleman Regency, Research Report of the Directorate of Research and Community Service (DPPM) of the Indonesian Islamic University, Report, (in Bahasa) (2011)

18. Newhall C G, Bronto S, Alloway B, Banks N G, Bahar I, del Marmol M A, Hadisantono R D, Holcom R T, McGeehin J, Miksic J N, Rubin M, Sayudi S D, Sukhyar R, Andreastuti S, Tilling R I, Torley R, Trimble D, Wirakusumah A D, "10,000 Years of explosive eruptions of Merapi Volcano, Central Java : Archeological and modern implications", J. of Volc. and Geothermal Research 100(-), pp.9-50, (2000)

19. Wilson T M, Kaye G, Stewart C, Cole J W, Impact of 2006 eruption of Merapi volcano Indonesia on agricultural and infrastructure, GNS Science Report, 2007/7,(2007)

20. Hartini K S, Morphology Analysis of Merapi edifice in studying Merapi-type eruption, to improve volcanic hazard map, Master Thesis, Graduate School Faculty of GeographyGeoinformation Science and Earth Observation, University of Twente, (2010)

21. Beca Carter Hollings \& Ferner, Contingency Plan for the Auckland Volcanic Field, Auckland Regional Council, New Zealand, (2002)

22. Dhakhwa D R, Earthquake Contingency Plan, Nepal Red Cross Society, National Headquarters, Kathmandu,(2008)

23. Bakkour D, Enjolras D, Kars R, Thouret D.J, The adaptive governance of natural disaster: Insight from the 2010 Mount Merapi Eruption in Indonesia, LAMETA, Laboratoire Monpellierain, UMR, Report (2013)

24. Wulandari Y, Coffey M, Sagala S, The impact of Major Geological Hazards to Community Resilience in Indonesia, Resilience Development Initiative (RDI) Working Paper, (2016)

25. Mei E T W, Lafigne F, Population evacuation during the 2010 Merapi Volcano eruption, Special Edition of Merapi Volcano Eruption 2010, Vol. 2, p. 7-23 (in Bahasa), (2010)

26. Tuswadi, "Disaster Management and Prevention Education for Volcanic Eruption : A Case of Merapi Area Primary in Java Island Indonesia", Doctorate Dissertation , Graduate School for International Development and Cooperation, Hiroshima University, (2014). 